\title{
Histone ubiquitination and deubiquitination in transcription, DNA damage response, and cancer
}

\author{
Jian Cao* and Qin Yan* \\ Department of Pathology, Yale University School of Medicine, New Haven, CT, USA
}

\section{Edited by:}

Hui-Kuan Lin, The University of Texas MD Anderson Cancer Center, USA

\section{Reviewed by:}

Shiaw-Yih Lin, The University of Texas MD Anderson Cancer Center, USA Yan Liu, Indiana University, USA

\section{${ }^{*}$ Correspondence:}

Jian Cao and Qin Yan, Department of Pathology, Yale University School of Medicine, PO Box 208023, 310 Cedar Street, BML 338, New Haven, CT 06520-8023, USA.

e-mail: jian.cao@yale.edu;

gin.yan@yale.edu
Histone post-transcriptional modifications play essential roles in regulation of all DNA related processes. Among them, histone ubiquitination has been discovered for more than three decades. However, its functions are still less well understood than other histone modifications such as methylation and acetylation. In this review, we will summarize our current understanding of histone ubiquitination and deubiquitination. In particular, we will focus on how they are regulated by histone ubiquitin ligases and deubiquitinating enzymes. We will then discuss the roles of histone ubiquitination in transcription and DNA damage response and the crosstalk between histone ubiquitination and other histone modifications. Finally, we will review the important roles of histone ubiquitination in stem cell biology and cancer.

Keywords: ubiquitin ligases, deubiquitinating enzymes, DUBs, H2Aub, H2Bub, BRCA1, RNF20, USP22

\section{INTRODUCTION}

In the eukaryotic nucleus, genomic DNA is packaged into chromatin by forming nucleosomes. Each nucleosome core particle consists of a histone octamer which is wrapped by 146 base pairs of DNA (Luger et al., 1997). A histone octamer is composed of two copies of the core histones $\mathrm{H} 2 \mathrm{~A}, \mathrm{H} 2 \mathrm{~B}, \mathrm{H} 3$, and $\mathrm{H} 4$. The histone tails protrude from the nucleosome, and are subjected to a wide array of covalent modifications include methylation, acetylation, ubiquitination, phosphorylation, sumoylation, and ADP ribosylation (Strahl and Allis, 2000). These post-transcriptional modifications work together to regulate the chromatin structure, which affects biological processes including gene expression, DNA repair, and chromosome condensation. Recent advances have defined critical roles of histone ubiquitination in transcriptional regulation and DNA repair. The writers, erasers, and readers of histone ubiquitination have also been linked to cancer development.

\section{HISTONE UBIQUITINATION}

Histone $\mathrm{H} 2 \mathrm{~A}$ is the first protein identified to be modified by ubiquitin in cells (Goldknopf et al., 1975). We know now H2A and $\mathrm{H} 2 \mathrm{~B}$ are two of the most abundant ubiquitinated proteins in the nucleus. It is estimated that $5-15 \%$ of $\mathrm{H} 2 \mathrm{~A}$ and $1-2 \%$ of $\mathrm{H} 2 \mathrm{~B}$ are conjugated with ubiquitin in vertebrate cells, while about $10 \%$ of H2B are ubiquitinated in yeast cells (Goldknopf et al., 1975; Matsui et al., 1979; West and Bonner, 1980; Robzyk et al., 2000).

The dominant form of ubiquitinated histones are monoubiquitinated $\mathrm{H} 2 \mathrm{~A}(\mathrm{H} 2 \mathrm{Aub})$ and $\mathrm{H} 2 \mathrm{~B}(\mathrm{H} 2 \mathrm{Bub})$. A single molecule of ubiquitin is added to the highly conserved lysine residues: Lys-119 for H2A, and Lys-123 in yeast or Lys-120 in vertebrate for H2B (Figure 1; Goldknopf et al., 1975; West and Bonner, 1980). Chromatin immunoprecipitation (ChIP) experiments showed that monoubiquitinated $\mathrm{H} 2 \mathrm{~A}$ is enriched in the satellite regions of genome, while $\mathrm{H} 2 \mathrm{Bub}$ binds to the gene body of transcriptional active genes (Minsky et al., 2008; Shema et al., 2008; Zhu et al., 2011).
In addition to $\mathrm{H} 2 \mathrm{~A}$ and $\mathrm{H} 2 \mathrm{~B}$, core histones $\mathrm{H} 3, \mathrm{H} 4$, and linker histone $\mathrm{H} 1$ have also been reported to be modified by ubiquitin (Pham and Sauer, 2000; Jason et al., 2002; Wang et al., 2006; Jones et al., 2011). For example, H3 and H4 were polyubiquitinated in vivo by CUL4-DDB-RBX1 ubiquitin ligase complex after UV irradiation (Wang et al., 2006). But the biological function of these modifications has not been well elucidated.

Besides monoubiquitination, histone $\mathrm{H} 2 \mathrm{~A}$ and $\mathrm{H} 2 \mathrm{~B}$ can be modified by ubiquitin chains. K63-linked polyubiquitination of $\mathrm{H} 2 \mathrm{~A}$ and $\mathrm{H} 2 \mathrm{AX}$, a variant of $\mathrm{H} 2 \mathrm{~A}$, is usually induced by DNA damage and is required for DNA repair response (Huen et al., 2007; Kolas et al., 2007; Mailand et al., 2007; Wang and Elledge, 2007; Doil et al., 2009; Stewart et al., 2009). Like other proteins, formation of K48-linked ubiquitin chains on histones targets them for proteasome mediated degradation. For example, during spermatogenesis, histones are degraded through this mechanism and replaced by transition proteins to permit chromatin condensation (Chen et al., 1998; Liu et al., 2005).

\section{HISTONE UBIOUITINATION ENZYMES}

In this section, we will summarize our current knowledge on the histone modifying enzymes that can add ubiquitin to or remove it from histones (Figure 1; Table 1).

\section{HISTONE UBIQUITIN LIGASES}

Polycomb group protein RING1B is the first identified ubiquitin ligase (E3) responsible for monoubiquitination of $\mathrm{H} 2 \mathrm{~A}$ at lysine 119 (Wang et al., 2004; Cao et al., 2005). Loss of RING1B dramatically decreases $\mathrm{H} 2 \mathrm{~A}$ monoubiquitination globally and at the promoters of specific genes (Wang et al., 2004; Cao et al., 2005). Two other RING domain containing proteins in the PRC1 (Polycomb Repressive Complex 1) complex, RING1A, and BMI1, strongly stimulate the E3 ubiquitin ligase activity of RING1B (Cao et al., 2005; Buchwald et al., 2006). Another H2A-specific 


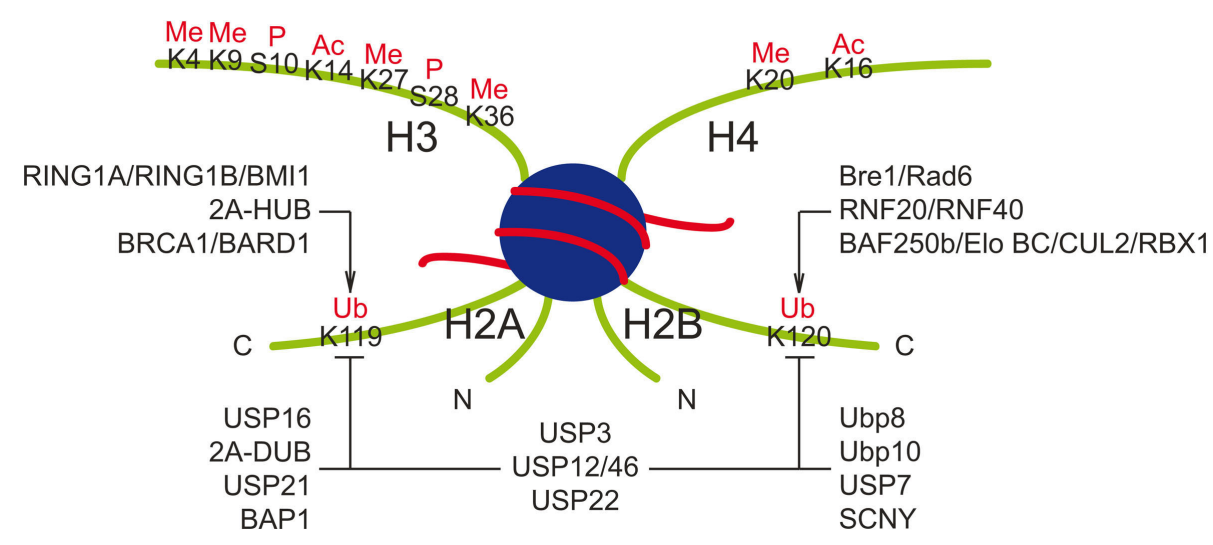

FIGURE 1 | Ubiquitin ligases and deubiquitinating enzymes responsible for monoubiquitination of histones H2A and H2B. Major post-transcriptional modifications on histone $\mathrm{H} 3$ and $\mathrm{H} 4$ tails are also shown. Ac, acetylation; Me, methylation; P, phosphorylation.

Table 1 | Functions of histone modifying enzymes for monoubiquitination.

\begin{tabular}{|c|c|c|c|c|c|}
\hline Enzyme & Species & $\begin{array}{l}\text { Histone } \\
\text { specificity }\end{array}$ & $\begin{array}{l}\text { Enzymatic } \\
\text { activity }\end{array}$ & $\begin{array}{l}\text { Role in } \\
\text { transcription }\end{array}$ & Reference \\
\hline RING1A/RING1B/BMI1 & Human & $\mathrm{H} 2 \mathrm{~A}$ & E3 & Repression & Cao et al. (2005); Gearhart et al. (2006) \\
\hline BRCA1/BARD1 & Human & $\mathrm{H} 2 \mathrm{~A}$ & E3 & Repression & Chen et al. (2002); Zhu et al. (2011) \\
\hline UbcH5c & Human & $\mathrm{H} 2 \mathrm{~A}$ & E2 & N/A & Chen et al. (2002) \\
\hline Bre1 & Yeast & $\mathrm{H} 2 \mathrm{~B}$ & E3 & Activation & Robzyk et al. (2000); Kao et al. (2004) \\
\hline RNF20/40 & Human & $\mathrm{H} 2 \mathrm{~B}$ & E3 & Activation & Kim et al. (2005); Prenzel et al. (2011) \\
\hline RAD6A/B & Human & $\mathrm{H} 2 \mathrm{~B}$ & E2 & Activation & Kim et al. (2005) \\
\hline UbcH6 & Human & $\mathrm{H} 2 \mathrm{~B}$ & E2 & Activation & Zhu et al. (2005) \\
\hline USP16 & Human & $\mathrm{H} 2 \mathrm{~A}$ & DUB & Activation & Joo et al. (2007); Shanbhag et al. (2010) \\
\hline USP21 & Human & $\mathrm{H} 2 \mathrm{~A}$ & DUB & Activation & Nakagawa et al. (2008) \\
\hline 2A-DUB & Human & $\mathrm{H} 2 \mathrm{~A}$ & DUB & Activation & Zhu et al. (2007) \\
\hline Ubp7 & Drosophila & $\mathrm{H} 2 \mathrm{~B}$ & DUB & Repression & van der Knaap et al. (2005) \\
\hline SCNY & Drosophila & $\mathrm{H} 2 \mathrm{~B}$ & DUB & Repression & Buszczak et al. (2009) \\
\hline UBP12/46 & Xenopus & $\mathrm{H} 2 \mathrm{~A} \mathrm{H} 2 \mathrm{~B}$ & DUB & Activation & Joo et al. (2011) \\
\hline USP3 & Human & $\mathrm{H} 2 \mathrm{~A} \mathrm{H} 2 \mathrm{~B}$ & DUB & N/A & Nicassio et al. (2007) \\
\hline USP22 & Human & $\mathrm{H} 2 \mathrm{~A} \mathrm{H} 2 \mathrm{~B}$ & DUB & Activation & Zhang et al. (2008); Zhao et al. (2008) \\
\hline
\end{tabular}

E3, 2A-HUB/hRUL138 is recruited by the NCoR/HDAC1/3 complex and catalyzes H2A monoubiquitination at Lysine 119 (Zhou et al., 2008). Breast cancer type 1 susceptibility gene (BRCA1) is also a potential E3 ubiquitin ligase for histone H2A. In an in vitro ubiquitination assay, BRCA1 cooperates with ubiquitinconjugating enzyme (E2) $\mathrm{UbcH} 5 \mathrm{c}$ to catalyze monoubiquitination of H2A/H2AX (Chen et al., 2002). In an in vivo study, BRCA1 colocalizes with $\mathrm{H} 2 \mathrm{Aub}$ on satellite DNA, and loss of BRCA1 results in the decrease of H2Aub occupation in these regions (Zhu et al., 2011). Another RING finger containing protein BARD1, which carries an enzyme dead mutation in its RING finger, binds to BRCA1 and enhances its E3 activity (Xia et al., 2003). Although several ubiquitin ligases can catalyze $\mathrm{H} 2 \mathrm{~A}$ monoubiquitination, loss of RING1A, RING1B, or BMI1 leads to global decrease of
H2Aub, suggesting the RING1A/RING1B/BMI1 complex is the major E3 in mammalian cells (de Napoles et al., 2004; Wang et al., 2004; Cao et al., 2005; Stock et al., 2007).

The enzymes responsible for $\mathrm{H} 2 \mathrm{~B}$ monoubiquitination were first identified in yeast: Rad6 as a ubiquitin-conjugating enzyme and Brel as a ubiquitin ligase (Robzyk et al., 2000; Hwang et al., 2003; Wood et al., 2003; Kao et al., 2004). There are two homologs of Bre1 in mammalian cells: RNF20 and RNF40 (Koken et al., 1991; Kim et al., 2005). RNF20 and RNF40 form a complex in vivo, associate with yRad6 homologs hRAD6A and hRAD6B, or another ubiquitin-conjugating enzyme UbcH6, and catalyze monoubiquitination of $\mathrm{H} 2 \mathrm{~B}$ at lysine 120 in vitro (Kim et al., 2005, 2009; Zhu et al., 2005). Knockdown of RNF20 or RNF40 significantly reduces H2Bub globally in human cells (Kim et al., 2005; Zhu et al., 2005). 
The SWI/SNF-A subunit BAF250b associates with Elongin B and $\mathrm{C}$, CUL2, and RBX1 to form a canonical Elongin BC containing ubiquitin ligase complex similar to the VHL or E4orf6 complex (Kamura et al., 1999; Querido et al., 2001; Yan et al., 2004). This BAF250b complex can also catalyze H2B monoubiquitination (Li et al., 2010).

Histones $\mathrm{H} 2 \mathrm{~A}$ and $\mathrm{H} 2 \mathrm{AX}$ can also be polyubiquitinated by a related ubiquitin ligase complex. RNF8 and RNF168 catalyze formation of K63-linked polyubiquitination chain in histones $\mathrm{H} 2 \mathrm{~A}$ and $\mathrm{H} 2 \mathrm{AX}$ at the site of DNA damage during DNA damage repair (Stewart et al., 2009). Polyubiquitination of H2A and H2AX facilitates the accumulation of DNA repair proteins including 53BP1 and BRCA1 at the DNA damage foci (Huen et al., 2007; Kolas et al., 2007; Mailand et al., 2007; Wang and Elledge, 2007; Doil et al., 2009; Stewart et al., 2009).

\section{HISTONE DEUBIQUITINATING ENZYMES}

Like other histone modifications, monoubiquitination of histones $\mathrm{H} 2 \mathrm{~A}$ and $\mathrm{H} 2 \mathrm{~B}$ is reversible. The ubiquitin modification can be removed by ubiquitin specific peptidases known as deubiquitinating enzymes (DUBs).

Several DUBs, including USP16, 2A-DUB, USP21, and BRCA1 associated protein 1 (BAP1) were identified as $\mathrm{H} 2 \mathrm{~A}$-specific. USP16 catalyzes $\mathrm{H} 2 \mathrm{~A}$ deubiquitination in vitro and in vivo, and plays important roles in $\mathrm{H} 2 \mathrm{Aub}$ mediated $\mathrm{HOX}$ gene silencing, $\mathrm{X}$ chromosome inactivation, cell cycle progression, and DNA damage repair (Joo et al., 2007; Shanbhag et al., 2010). 2A-DUB interacts with PCAF and is required for full activation of androgen receptor-dependent genes (Zhu et al., 2007). Another H2A-specific DUB, USP21, was identified as a regulator of liver regeneration by deubiquitination of $\mathrm{H} 2 \mathrm{Aub}$ at the promoters of regeneration related genes (Nakagawa et al., 2008). The polycomb protein BAP1, was identified as an $\mathrm{H} 2 \mathrm{~A}$-specific histone C-terminal hydrolase. BAP1 removes monoubiquitin from $\mathrm{H} 2 \mathrm{~A}$ but not $\mathrm{H} 2 \mathrm{~B}$ in vivo and in vitro. Loss of BAP1 significantly increases $\mathrm{H} 2 \mathrm{Aub}$ level and abolishes the repression of HOX genes in flies (Scheuermann et al., 2010).

Ubp8 and Ubp10 were identified as histone H2B DUBs in yeast (Henry et al., 2003; Daniel et al., 2004; Emre et al., 2005), but they have very different functions. Ubp8 co-localizes with $\mathrm{H} 3 \mathrm{~K} 4 \mathrm{me} 3$, while Ubp10 binds to $\mathrm{H} 3 \mathrm{~K} 79$ me3 enriched sites, as well as telomere and rDNA locus (Emre et al., 2005; Schulze et al., 2011). Ubp8 catalyzes $\mathrm{H} 2 \mathrm{~B}$ deubiquitination in vitro and loss of Ubp8 increases the global level of H2Bub (Henry et al., 2003; Daniel et al., 2004), suggesting that Ubp8 is the major H2Bub DUB in yeast. Furthermore, as a component of the SAGA acetylation complex, Ubp8 is required for the transcription of SAGA-regulated genes (Henry et al., 2003). In addition, USP7 has been shown to catalyze H2B deubiquitination and mediate epigenetic silencing of homeotic genes (van der Knaap et al., 2005). Drosophila ubiquitin protease SCNY, a homolog of yeast Ubp10, deubiquitinates monoubiquitinated H2B in vitro (Buszczak et al., 2009). Loss of SCNY increases monoubiquitinated H2B in larvae (Buszczak et al., 2009). Interestingly, SCNY is required for maintaining multiple types of adult stem cells (Buszczak et al., 2009).

In addition to $\mathrm{H} 2 \mathrm{~A}$ or $\mathrm{H} 2 \mathrm{~B}$ specific DUBs, several DUBs display dual specificity toward both $\mathrm{H} 2 \mathrm{Aub}$ and $\mathrm{H} 2 \mathrm{Bub}$, such as USP3,
USP12, and USP46. USP3 is required for cell cycle progression and genome stability, while USP12 and USP46 regulate Xenopus development (Nicassio et al., 2007; Joo et al., 2011). The Ubp8 homolog USP22 is a subunit of coactivator acetyltransferase hSAGA complex. It is recruited to the promoters by activators to deubiquitinate $\mathrm{H} 2 \mathrm{~A}$ and $\mathrm{H} 2 \mathrm{~B}$, and is required for transcription activation (Zhang et al., 2008; Zhao et al., 2008).

Multiple histone DUBs were identified, suggesting that they may have redundant functions or act in a context-dependent manner. Although their redundancy was not extensively investigated, current literature supports the notion that these DUBs have context-dependent functions in various processes. Their functions may also be dictated by their expression patterns in different tissues and stages during development.

\section{FUNCTION OF HISTONE UBIOUITINATION}

As histones are the most abundant ubiquitinated proteins, their ubiquitination plays critical roles in many processes in the nucleus, including transcription, maintenance of chromatin structure, and DNA repair.

\section{TRANSCRIPTION}

Monoubiquitination of $\mathrm{H} 2 \mathrm{~A}$ and $\mathrm{H} 2 \mathrm{~B}$ have been clearly implicated in transcriptional regulation. $\mathrm{H} 2 \mathrm{Aub}$ occupation is more frequently correlated with gene silencing, while $\mathrm{H} 2 \mathrm{Bub}$ is mostly associated with transcription activation.

$\mathrm{H} 2 \mathrm{~A}$ ubiquitin ligases were found in transcription repressor complexes, such as the PRC1, BCoR, E2F6.com-1, and 2A-HUB complexes (Ogawa et al., 2002; Wang et al., 2004; Cao et al., 2005; Gearhart et al., 2006; Zhou et al., 2008). RING1B mediated $\mathrm{H} 2 \mathrm{Aub}$ is required for polycomb targeted gene silencing (CaO et al., 2005). Furthermore, in an in vitro assay, H2Aub represses transcriptional initiation and inhibits the formation of transcriptional active markers H3K4me2 and me3 (Nakagawa et al., 2008). The fact that H2A DUBs are usually required for genes activation (Joo et al., 2007; Zhu et al., 2007; Zhao et al., 2008) provides a second line of evidence for the gene silencing function of H2Aub.

In contrast, $\mathrm{H} 2 \mathrm{Bub}$ occupation is strongly correlated with active gene expression in most cases, likely through multiple mechanisms, including promoting other active histone modifications and Pol II elongation. In a ChIP-on-Chip experiment, $\mathrm{H} 2 \mathrm{~B}$ monoubiquitination was found in the transcribed regions of highly expressed genes (Minsky et al., 2008). In yeast, monoubiquitinated $\mathrm{H} 2 \mathrm{~B}$ is required for the COMPASS complex for di- and tri-methylation of $\mathrm{H} 3$ at lysine 4 (Dover et al., 2002; Sun and Allis, 2002; Lee et al., 2007a), which are active markers for transcription (Klose et al., 2007; Blair et al., 2011). Loss of E2, E3, or the ubiquitination site (K123) within H2B inhibits H3K4 methylation by the COMPASS complex (Sun and Allis, 2002; Wood et al., 2003). In mammalian cells, E2 UbcH6 and E3 complex RNF20/RNF40 are recruited to transcriptionally active genes (Zhu et al., 2005). RNF20 also binds to transcription factors such as p53 directly and functions as a coactivator (Kim et al., 2005). Overexpression of RNF20 leads to elevated H2B monoubiquitination globally, which leads to subsequent increase of methylation at lysine 4 and 79 in $\mathrm{H} 3$, and stimulation of HOX gene expression (Zhu et al., 2005). Conversely, knockdown of RNF20 decreases endogenous H2Bub, 
H3K4, and K79 methylation, and therefore transcription (Kim et al., 2005). Moreover, transcriptional regulation by RNF20 is dependent on its E3 ligase activity (Shema et al., 2011).

Recent work implicated the function of $\mathrm{H} 2 \mathrm{Bub}$ in regulating transcriptional elongation, suggesting that it is also a mechanism by which $\mathrm{H} 2 \mathrm{Bub}$ plays a positive role in gene expression. $\mathrm{H} 2 \mathrm{~B}$ ubiquitination is associated with elongating RNA Polymerase II, and is necessary for reassembly of nucleosomes and restoration of the chromatin structure during the transcription elongation, thus influencing the kinetic properties of elongating Pol II (Xiao et al., 2005). Using a reconstituted chromatin transcription system, Reinberg and colleagues showed that $\mathrm{H} 2 \mathrm{Bub}$ stimulates elongation by Pol II through the chromatin by promoting the replacement of $\mathrm{H} 2 \mathrm{~A} / \mathrm{H} 2 \mathrm{~B}$ dimers from the core nucleosomes (Pavri et al., 2006). A recent study showed that monoubiquitinated $\mathrm{H} 2 \mathrm{~B}$ cooperates with acetylated $\mathrm{H} 4$ to disrupt chromatin compaction, which leads to an open and accessible chromatin structure (Fierz et al., 2011). Furthermore, yeast mutants carrying defects in H2B ubiquitination pathway display transcription elongation defects (Xiao et al., 2005).

However, H2B monoubiquitination may also repress gene expression in some cases. H2B DUBs, for example, were found in some coactivator complexes and they are required for coactivatordependent gene activation in both yeast and mammalian cells (Henry et al., 2003; Zhang et al., 2008; Zhao et al., 2008). One of these DUBs, Ubp8, promotes Pol II CTD phosphorylation, which is a mark of transcription elongation and is required for co-transcriptional mRNA processing (Wyce et al., 2007). Both E3s and DUBs of $\mathrm{H} 2 \mathrm{Bub}$ showed a positive effect on gene activation, suggesting the ubiquitination and deubiquitination cycle of $\mathrm{H} 2 \mathrm{~B}$ is required for full gene induction (Henry et al., 2003; Wyce et al., 2007).

Many studies demonstrated that histone ubiquitination and other histone modifications are inter-connected and they act in combination and/or sequentially to regulate transcription. For example, H2B monoubiquitination is required for both $\mathrm{H} 3 \mathrm{~K} 4$ methylation and H3K79 methylation (Dover et al., 2002; Sun and Allis, 2002; Lee et al., 2007a). H3K27 demethylase UTX was shown to suppress the recruitment of PRC1 and subsequent $\mathrm{H} 2 \mathrm{~A}$ monoubiquitination (Lee et al., 2007b). It was also shown that $\mathrm{H} 2 \mathrm{~A}$ monoubiquitination is coupled to H3K36me2 demethylation (Lagarou et al., 2008). These findings indicate that precise transcriptional control requires the concerted actions of multiple histone modifications.

\section{DNA DAMAGE RESPONSE}

Current studies suggest that histone ubiquitination is a general histone modification induced by DNA damage and plays important roles in DNA damage response. DNA damage has emerged as a major culprit in cancer and many other diseases. Inherited impairments in DNA repair usually leads to a higher risk of cancer. Cells developed a defense system against DNA damage, called DNA damage response, which includes recruitment of DNA repair machinery, cell cycle arrest, and lesion tolerance or apoptosis (Hoeijmakers, 2001).

One of the classic models to trigger DNA damage response is to introduce DNA double-strand break (DSB). Following DSBs, the histone variant $\mathrm{H} 2 \mathrm{AX}$ is rapidly phosphorylated at the $\gamma$ position $(\gamma \mathrm{H} 2 \mathrm{AX})$ along chromatin tracks flanking DSBs by ATM, ATR, and DNA-PK (Falck et al., 2005). H2AX phosphorylation facilitates the accumulation of DNA damage response regulators, Mdc1/NFBD1(Stewart et al., 2003; Xu and Stern, 2003), RNF8 and RNF168. RNF8 and RNF168 catalyze the K63-linked polyubiquitination chain formation on histone $\mathrm{H} 2 \mathrm{~A}$ and $\mathrm{H} 2 \mathrm{AX}$ (Huen et al., 2007; Kolas et al., 2007; Mailand et al., 2007; Stewart et al., 2009). K63-linked polyubiquitinated histones provide a recognition element that recruits RAP80 through its ubiquitin interaction motif (Kim et al., 2007; Sobhian et al., 2007; Wang et al., 2007). The subsequent recruitment of BRCA1 and the intact IR induced G2/M checkpoint are dependent on RAP80 and its ubiquitin binding motif that recognizes K63-linked polyubiquitin chains on H2A and H2AX (Kim et al., 2007; Sobhian et al., 2007; Wang and Elledge, 2007; Wang et al., 2007). Consistent with these findings, knockdown of histone ubiquitination enzymes impairs DSB-associated polyubiquitination of $\mathrm{H} 2 \mathrm{~A}$ and $\mathrm{H} 2 \mathrm{AX}$, inhibits retention of 53BP1 and BRCA1 at the DSB sites, and sensitizes cells to ionizing radiation (Huen et al., 2007; Kolas et al., 2007; Mailand et al., 2007; Stewart et al., 2009).

In addition to polyubiquitination, monoubiquitination of histones $\mathrm{H} 2 \mathrm{~A}, \mathrm{H} 2 \mathrm{~B}$, and $\mathrm{H} 2 \mathrm{AX}$ also occurs at the sites of DNA damage. RING1B/BMI1 and RNF20/RNF40 are recruited to DSB site and catalyze $\mathrm{H} 2 \mathrm{~A} / \mathrm{H} 2 \mathrm{AX}$ monoubiquitination at lysine 119 and $\mathrm{H} 2 \mathrm{~B}$ monoubiquitination at lysine 120 , respectively (Bergink et al., 2006; Marteijn et al., 2009; Wu et al., 2009, 2011; Ginjala et al., 2011; Moyal et al., 2011; Pan et al., 2011). Furthermore, depletion of RNF20 or interference with histone H2B monoubiquitination disrupts the recruitment of DNA repair machine proteins in both non-homologous end joining (NHEJ) and homologous recombination repair (HRR) pathways to the DSB (Moyal et al., 2011). Histone DUBs, such as USP3 and K63-ub DUB BRCC36, are also critical for efficient DNA repair, suggesting that a dynamic regulation of histone ubiquitination and deubiquitination is required for DNA damage response (Shao et al., 2009). It was proposed that monoubiquitination of histones $\mathrm{H} 2 \mathrm{~A}$ and $\mathrm{H} 2 \mathrm{~B}$ interferes with chromatin compaction and therefore facilitates assembly of the repair machinery on the DNA damage foci (Moyal et al., 2011), but the mechanisms of action remain elusive.

\section{OTHER FUNCTIONS}

$\mathrm{H} 2 \mathrm{~A}$ monoubiquitination occurs on the inactive $\mathrm{X}$ chromosome in female mammals (de Napoles et al., 2004; Fang et al., 2004). Both RING1B and H2Aub are involved in the initiation of imprinted and random X chromosome inactivation (de Napoles et al., 2004; Fang et al., 2004).

In addition to transcription regulation, monoubiquitinated $\mathrm{H} 2 \mathrm{~B}$ is required for chromatin function in other ways. H2Bub is required for chromatin boundary integrity, and loss of $\mathrm{H} 2 \mathrm{Bub}$ leads to the spreading of other histone modifications (Ma et al., 2011). The present of H2Bub also interferes with chromatin compaction and results in an open chromatin structure (Fierz et al., 2011). H2Bub is also shown to play an important role in homologous recombination through chromatin remodeling by recruiting chromatin remodeling factors. Cells lacking RNF20 or expressing H2B K120R, which lacks ubiquitin conjugation site, exhibit defects in HRR (Nakamura et al., 2011). 
Histone ubiquitination and deubiquitination play essential roles in stem cell maintenance and differentiation, likely through controlling the expression of key pluripotency and differentiation genes. BMI1 is required for the self-renewal and maintenance of hematopoietic stem cells (Lessard and Sauvageau, 2003; Park et al., 2003) and neural stem cells (Molofsky et al., 2003). In flies, $\mathrm{H} 2 \mathrm{~B}$ DUB SCNY is required for the maintenance of germline stem cells, follicle stem cells, and intestinal stem cells. SCNY mutant animals display reduced number and half-life of germline stem cells (Buszczak et al., 2009). In mouse embryonic stem cells, ubiquitinated $\mathrm{H} 2 \mathrm{~A}$ restrains poised RNA polymerase II at a subset of developmental regulator genes. Loss of RING1A and RING1B releases poised RNA polymerase II and subsequent gene de-repression (Stock et al., 2007).

Furthermore, a recent landmark paper showed that H2Bub can function in trans independent of transcription (Latham et al., 2011). During mitosis, H2Bub is required for the kinetochore protein Dam1 methylation (Latham et al., 2011). Depletion of E2, E3 for H2B monoubiquitination or mutation of Lys-123 in H2B inhibits methylation of Dam1 (Latham et al., 2011). These results suggest that $\mathrm{H} 2 \mathrm{Bub}$ also plays important roles outside of chromatin and is required for chromosome segregation.

\section{HISTONE UBIQUITINATION AND CANCER}

Histone modifications play critical roles in genes expression and DNA repair. Aberrations of these processes often cause cancers (Jones and Baylin, 2007). Many histone modifying enzymes have been identified as oncogene or tumor suppressors (Chandrasekharappa et al., 1997; Yokoyama et al., 2004; Wissmann et al., 2007; Lin et al., 2011). Therefore, it is not a surprise that more and more connections between histone ubiquitination and cancer have been discovered. Monoubiquitinated histone $\mathrm{H} 2 \mathrm{~A}$ and $\mathrm{H} 2 \mathrm{~B}$ were found to be dramatically down-regulated in prostate and breast tumors, respectively (Zhu et al., 2007; Prenzel et al., 2011). Recently advances have also linked the writers, erasers, and readers of histone ubiquitination to tumorigenesis.

\section{BRCA1}

Inactivation of tumor suppressor BRCA1 leads to breast and ovarian cancer. Female individuals carrying a mutated BRCA1 allele have an estimated risk of $87 \%$ for breast cancer and $44 \%$ for ovarian cancer by age 70 (Ford et al., 1994). BRCA1 associated protein BAP1 is also a tumor suppressor in multiple cancers, including lung cancer, breast cancer, uveal melanoma, and mesothelioma (Harbour et al., 2010; Testa et al., 2011; Wiesner et al., 2011).

The BRCA1 protein is a RING finger domain containing E3 ubiquitin ligase. H2A and H2B were identified as BRCA1 substrates in an in vitro assay (Chen et al., 2002; Mallery et al., 2002). A more recently report showed that BRCA1 binds to satellite DNA regions and catalyzes monoubiquitination of $\mathrm{H} 2 \mathrm{~A}$ in vivo (Zhu et al., 2011). Loss of BRCA1 is associated with loss of H2A ubiquitination at satellite repeats and de-repression of satellite transcription. Cells lacking BRCA1 are impaired in organization of heterochromatin structure. More interestingly, ectopic expression of $\mathrm{H} 2 \mathrm{~A}$ fused to ubiquitin, which is a mimic of natural monoubiquitinated H2A, rescues BRCA1 phenotypes (Zhu et al., 2011). These findings indicate that BRCA1 maintains heterochromatin structure via monoubiquitination of H2A. Furthermore, the fact that satellite DNA transcripts are increased in BRCA1 mutant breast cancer samples, and the relationship between monoubiquitination of $\mathrm{H} 2 \mathrm{~A}$ and satellite DNA repression suggest that dysregulation of $\mathrm{H} 2 \mathrm{Aub}$ plays important roles in tumorigenesis.

\section{RNF20 AND RNF40}

RNF20 is the major H2B specific E3 ubiquitin ligase in mammalian cells. Besides a significant decrease in the cellular pool of monoubiquitinated H2B, RNF20 depletion causes increased expression of some proto-oncogenes and growth-related genes including c-myc and c-Fos (Shema et al., 2008). Further study discovered that RNF20 represses gene expression by disrupting the interaction between TFIIS and PAF1 elongation complex and inhibiting transcriptional elongation. Those effects are also dependent on the E3 ligase activity of RNF20 (Shema et al., 2011). In addition, RNF20 depleted cells showed decreased expression of the p53 tumor suppressor, and increased cell migration and tumorigenesis. Moreover, hypermethylation of RNF20 promoter was observed in tumor samples (Shema et al., 2008). These findings suggest that $\mathrm{H} 2 \mathrm{~B}$ ubiquitin ligase RNF20 is a putative tumor suppressor. Furthermore, the RNF40, a binding partner of RNF20 and another major E3 for H2B monoubiquitination also showed tumor suppressive activity in breast cancer cells (Prenzel et al., 2011).

\section{USP22}

USP22 is a ubiquitin hydrolase and catalyzes the removal of ubiquitin from monoubiquitinated histones $\mathrm{H} 2 \mathrm{~A}$ and $\mathrm{H} 2 \mathrm{~B}$ (Zhang et al., 2008, 2011; Zhao et al., 2008). USP22 is a putative cancer stem cell marker and was found to be highly expressed in malignant tumor samples. High level of USP22 in tumor tissues is associated with poor clinical outcome, including high risk of recurrence, metastasis, and resistance to chemotherapy (Glinsky, 2005; Glinsky et al., 2005; Zhang et al., 2011). Further studies determined that USP22 is recruited to the gene promoters by Myc and is required for the activation of Myc target genes (Zhang et al., 2008). Depletion of USP22 compromises Myc functions, including transformation. USP22 also play roles in cell cycle regulation, where depletion of USP22 increases the expression of p53 and p21, inhibits proliferation, and induces cell cycle arrest at G1 phase (Zhang et al., 2008; Lv et al., 2011).

\section{CONCLUSION}

It is now well established that histone modifications and enzymes catalyzing their addition or removal are essential for normal cellular functions. Rapid advances of this field revealed that fine tuning of histone ubiquitination and deubiquitination is required for gene expression, DNA repair, and many other biological processes. Therefore aberrations of histone ubiquitination or deubiquitination lead to multiple human diseases including cancer. However, the precise mechanisms by which histone ubiquitination contributes to these biological processes are still poorly understood and require further investigation. Related essential questions include the crosstalk between histone ubiquitination and DNA methylation or other chromatin marks. Future studies that help decipher the essential roles of epigenetic regulation by histone 
ubiquitination in cellular homeostasis and pathological conditions like cancer will definitely benefit the identification of "druggable" targets for personalized cancer therapies.

\section{ACKNOWLEDGMENTS}

We thank members of the Yan laboratory for critical reading of the manuscript. This work was supported in part by V Scholar Award, Breast Cancer Alliance Young Investigator Grant, Melanoma Research Foundation Career Development Award, the Alexander and Margaret Stewart Trust Fellowship, CTSA Scholar Award from

\section{REFERENCES}

Bergink, S., Salomons, F. A., Hoogstraten, D., Groothuis, T. A., de Waard, H., Wu, J., Yuan, L., Citterio, E., Houtsmuller, A. B., Neefjes, J., Hoeijmakers, J. H., Vermeulen, W., and Dantuma, N. P. (2006). DNA damage triggers nucleotide excision repair-dependent monoubiquitylation of histone H2A. Genes Dev. 20, 1343-1352.

Blair, L. P., Cao, J., Zou, M. R., Sayegh, J., and Yan, Q. (2011). Epigenetic regulation by lysine demethylase 5 (KDM5) enzymes in cancer. Cancers 3, 1383-1404.

Buchwald, G., van der Stoop, P., Weichenrieder, O., Perrakis, A., van Lohuizen, M., and Sixma, T. K. (2006). Structure and E3-ligase activity of the ring-ring complex of polycomb proteins Bmil and Ringlb. EMBO J. 25, 2465-2474.

Buszczak, M., Paterno, S., and Spradling, A. C. (2009). Drosophila stem cells share a common requirement for the histone $\mathrm{H} 2 \mathrm{~B}$ ubiquitin protease scrawny. Science 323, 248-251.

Cao, R., Tsukada, Y., and Zhang, Y. (2005). Role of Bmi-1 and RinglA in $\mathrm{H} 2 \mathrm{~A}$ ubiquitylation and Hox gene silencing. Mol. Cell 20, 845-854.

Chandrasekharappa, S. C., Guru, S. C., Manickam, P., Olufemi, S. E., Collins, F. S., EmmertBuck, M. R., Debelenko, L. V., Zhuang, Z. P., Lubensky, I. A., Liotta, L. A., Crabtree, J. S., Wang, Y. P., Roe, B. A., Weisemann, J., Boguski, M. S., Agarwal, S. K., Kester, M. B., Kim, Y. S., Heppner, C., Dong, Q. H., Spiegel, A. M., Burns, A. L., and Marx, S. J. (1997). Positional cloning of the gene for multiple endocrine neoplasia-type 1. Science 276, 404-407.

Chen, A., Kleiman, F. E., Manley, J. L., Ouchi, T., and Pan, Z. Q. (2002). Autoubiquitination of the BRCA1BARD1 RING ubiquitin ligase. J. Biol. Chem. 277, 22085-22092.

Chen, H. Y., Sun, J. M., Zhang, Y., Davie, J. R., and Meistrich, M. L. (1998). Ubiquitination of histone $\mathrm{H} 3$ in elongating spermatids of rat testes. J. Biol. Chem. 273, 13165-13169.
Daniel, J. A., Torok, M. S., Sun, Z. W., Schieltz, D., Allis, C. D., Yates, J. R., 3rd, and Grant, P. A. (2004). Deubiquitination of histone $\mathrm{H} 2 \mathrm{~B}$ by a yeast acetyltransferase complex regulates transcription. J. Biol. Chem. 279, 1867-1871.

de Napoles, M., Mermoud, J. E., Wakao, R., Tang, Y. A., Endoh, M., Appanah, R., Nesterova, T. B., Silva, J., Otte, A. P., Vidal, M., Koseki, H., and Brockdorff, N. (2004). Polycomb group proteins Ring1A/B link ubiquitylation of histone $\mathrm{H} 2 \mathrm{~A}$ to heritable gene silencing and $\mathrm{X}$ inactivation. Dev. Cell 7, 663-676.

Doil, C., Mailand, N., Bekker-Jensen, S., Menard, P., Larsen, D. H., Pepperkok, R., Ellenberg, J., Panier, S., Durocher, D., Bartek, J., Lukas, J., and Lukas, C. (2009). RNF168 binds and amplifies ubiquitin conjugates on damaged chromosomes to allow accumulation of repair proteins. Cell 136, 435-446.

Dover, J., Schneider, J., Tawiah-Boateng, M. A., Wood, A., Dean, K., Johnston, M., and Shilatifard, A. (2002). Methylation of histone $\mathrm{H} 3$ by COMPASS requires ubiquitination of histone H2B by Rad6. J. Biol. Chem. 277, 28368-28371.

Emre, N. C., Ingvarsdottir, K., Wyce, A., Wood, A., Krogan, N. J., Henry, K. W., Li, K., Marmorstein, R., Greenblatt, J. F., Shilatifard, A., and Berger, S. L. (2005). Maintenance of low histone ubiquitylation by Ubp10 correlates with telomere-proximal Sir2 association and gene silencing. Mol. Cell 17, 585-594.

Falck, J., Coates, J., and Jackson, S. P. (2005). Conserved modes of recruitto sites of DNA damage. Nature 434, 605-611.

Fang, J., Chen, T., Chadwick, B., Li, E., and Zhang, Y. (2004). Ringlbmediated H2A ubiquitination associates with inactive $\mathrm{X}$ chromosomes and is involved in initiation of X inactivation. J. Biol. Chem. 279, 52812-52815.

Fierz, B., Chatterjee, C., McGinty, R. K., Bar-Dagan, M., Raleigh, D. P., ment of ATM, ATR and DNA-PKcs

Yale Center for Clinical Investigation, a Pilot Grant from the Yale Comprehensive Cancer Center (all to Qin Yan), and NIH grant CA16359 (to the Yale Comprehensive Cancer Center). This publication was made possible by CTSA Grant Number UL1 RR024139 from the National Center for Advancing Translational Sciences (NCATS), a component of the National Institutes of Health (NIH), and NIH roadmap for Medical Research. Its contents are solely the responsibility of the authors and do not necessarily represent the official view of NCATS or NIH. We apologize to our colleagues whose work could not be cited due to space limitation.

and Muir, T. W. (2011). Histone H2B ubiquitylation disrupts local and higher-order chromatin compaction. Nat. Chem. Biol. 7, 113-119.

Ford, D., Easton, D. F., Bishop, D. T. Narod, S. A., Goldgar, D. E., Haites, N., Milner, B., Allan, L., Ponder, B. A. J., Peto, J., Smith, S., Stratton, M., Lenoir, G. M., Feunteun, J., Lynch, H., Arason, A., Barkardottir, R., Egilsson, V., Black, D. M., Kelsell, D., Spurr, N., Devilee, P., Cornelisse, C. J., Varsen, H., Birch, J. M., Skolnick, M., Santibanezkoref, M. S., Teare, D., Steel, M., Porter, D. Cohen, B. B., Carothers, A., Smyth, E., Weber, B., Newbold, B., Boehnke, M., Collins, F. S., Cannonalbright, L. A., and Goldgar, D. (1994). Risks of cancer in BRCA1-mutation carriers. Lancet 343, 692-695.

Gearhart, M. D., Corcoran, C. M. Wamstad, J. A., and Bardwell, V. J. (2006). Polycomb group and SCF ubiquitin ligases are found in a novel BCOR complex that is recruited to BCL6 targets. Mol. Cell. Biol. 26, 6880-6889.

Ginjala, V., Nacerddine, K., Kulkarni, A., Oza, J., Hill, S. J., Yao, M., Citterio, E., van Lohuizen, M., and Ganesan, S. (2011). BMI1 is recruited to DNA breaks and contributes to DNA damage-induced H2A ubiquitination and repair. Mol. Cell. Biol. 31, 1972-1982.

Glinsky, G. V. (2005). Death-fromcancer signatures and stem cell contribution to metastatic cancer. Cell Cycle 4, 1171-1175.

Glinsky, G. V., Berezovska, O., and Glinskii, A. B. (2005). Microarray analysis identifies a death-fromcancer signature predicting therapy failure in patients with multiple types of cancer. J. Clin. Invest. 115, 1503-1521.

Goldknopf, I. L., Taylor, C. W., Baum, R. M., Yeoman, L. C., Olson, M. O., Prestayko, A. W., and Busch, H. (1975). Isolation and characterization of protein A24, a "histone-like" non-histone chromosomal protein. J. Biol. Chem. 250, 7182-7187.
Harbour, J. W., Onken, M. D., Roberson, E. D., Duan, S., Cao, L., Worley, L. A., Council, M. L., Matatall, K. A., Helms, C., and Bowcock, A. M. (2010). Frequent mutation of BAP1 in metastasizing uveal melanomas. Science 330, 1410-1413.

Henry, K. W., Wyce, A., Lo, W. S., Duggan, L. J., Emre, N. C., Kao, C. F. Pillus, L., Shilatifard, A., Osley, M. A., and Berger, S. L. (2003). Transcriptional activation via sequential histone $\mathrm{H} 2 \mathrm{~B}$ ubiquitylation and deubiquitylation, mediated by SAGAassociated Ubp8. Genes Dev. 17, 2648-2663.

Hoeijmakers, J. H. J. (2001). Genome maintenance mechanisms for preventing cancer. Nature 411,366-374.

Huen, M. S., Grant, R., Manke, I., Minn, K., Yu, X., Yaffe, M. B., and Chen, J. (2007). RNF8 transduces the DNAdamage signal via histone ubiquitylation and checkpoint protein assembly. Cell 131, 901-914.

Hwang, W. W., Venkatasubrahmanyam, S., Ianculescu, A. G., Tong, A., Boone, C., and Madhani, H. D. (2003). A conserved RING finger protein required for histone $\mathrm{H} 2 \mathrm{~B}$ monoubiquitination and cell size control. Mol. Cell 11, 261-266.

Jason, L. J., Moore, S. C., Lewis, J. D., Lindsey, G., and Ausio, J. (2002). Histone ubiquitination: a tagging tail unfolds? Bioessays 24, 166-174.

Jones, J. M., Bhattacharyya, A., Simkus, C., Vallieres, B., Veenstra, T. D., and Zhou, M. (2011). The RAG1 V(D)J recombinase/ubiquitin ligase promotes ubiquitylation of acetylated, phosphorylated histone 3.3. Immunol. Lett. 136, 156-162.

Jones, P. A., and Baylin, S. B. (2007). The epigenomics of cancer. Cell 128, 683-692.

Joo, H. Y., Jones, A., Yang, C., Zhai, L., Smith, A. D. T., Zhang, Z., Chandrasekharan, M. B., Sun, Z. W., Renfrow, M. B., Wang, Y., Chang, C., and Wang, H. (2011). Regulation of histone $\mathrm{H} 2 \mathrm{~A}$ and $\mathrm{H} 2 \mathrm{~B}$ deubiquitination and Xenopus development by USP12 and USP46. J. Biol. Chem. 286, 7190-7201. 
Joo, H. Y., Zhai, L., Yang, C., Nie, S., Erdjument-Bromage, H., Tempst, P., Chang, C., and Wang, H. (2007). Regulation of cell cycle progression and gene expression by H2A deubiquitination. Nature 449, 1068-1072.

Kamura, T., Conrad, M. N., Yan, Q., Conaway, R. C., and Conaway, J. W. (1999). The Rbxl subunit of SCF and VHL E3 ubiquitin ligase activates Rub1 modification of cullins Cdc53 and Cul2. Genes Dev. 13, 2928-2933.

Kao, C. F., Hillyer, C., Tsukuda, T., Henry, K., Berger, S., and Osley, M. A. (2004). Rad6 plays a role in transcriptional activation through ubiquitylation of histone H2B. Genes Dev. 18, 184-195.

Kim, H., Chen, J., and Yu, X. (2007). Ubiquitin-binding protein RAP80 mediates BRCA1-dependent DNA damage response. Science 316, 1202-1205.

Kim, J., Guermah, M., McGinty, R. K., Lee, J. S., Tang, Z., Milne, T. A., Shilatifard, A., Muir, T. W., and Roeder, R. G. (2009). RAD6-mediated transcription-coupled $\mathrm{H} 2 \mathrm{~B}$ ubiquitylation directly stimulates $\mathrm{H} 3 \mathrm{~K} 4$ methylation in human cells. Cell 137, 459-471.

Kim, J., Hake, S. B., and Roeder, R. G. (2005). The human homolog of yeast BRE1 functions as a transcriptional coactivator through direct activator interactions. Mol. Cell 20, 759-770.

Klose, R. J., Yan, Q., Tothova, Z., Yamane, K., Erdjument-Bromage, H., Tempst, P., Gilliland, D. G., Zhang, Y., and Kaelin, W. G. Jr. (2007). The retinoblastoma binding protein RBP2 is an H3K4 demethylase. Cell 128, 889-900.

Koken, M. H., Reynolds, P., JaspersDekker, I., Prakash, L., Prakash, S., Bootsma, D., and Hoeijmakers, J. H. (1991). Structural and functional conservation of two human homologs of the yeast DNA repair gene RAD6. Proc. Natl. Acad. Sci. U.S.A. 88, 8865-8869.

Kolas, N. K., Chapman, J. R., Nakada, S., Ylanko, J., Chahwan, R., Sweeney, F. D., Panier, S., Mendez, M., Wildenhain, J., Thomson, T. M., Pelletier, L., Jackson, S. P., and Durocher, D. (2007). Orchestration of the DNA-damage response by the RNF8 ubiquitin ligase. Science 318, 1637-1640.

Lagarou, A., Mohd-Sarip, A., Moshkin, Y. M., Chalkley, G. E., Bezstarosti, K., Demmers, J. A., and Verrijzer, C. P. (2008). dKDM2 couples histone $\mathrm{H} 2 \mathrm{~A}$ ubiquitylation to histone
H3 demethylation during polycomb group silencing. Genes Dev. 22, 2799-2810.

Latham, J. A., Chosed, R. J., Wang, S., and Dent, S. Y. (2011). Chromatin signaling to kinetochores: transregulation of Daml methylation by histone H2B ubiquitination. Cell 146, 709-719.

Lee, J. S., Shukla, A., Schneider, J., Swanson, S. K., Washburn, M. P., Florens, L., Bhaumik, S. R., and Shilatifard, A. (2007a). Histone crosstalk between H2B monoubiquitination and $\mathrm{H} 3$ methylation mediated by COMPASS. Cell 131, 1084-1096.

Lee, M. G., Villa, R., Trojer, P., Norman, J., Yan, K. P., Reinberg, D., Di Croce, L., and Shiekhattar, R. (2007b). Demethylation of H3K27 regulates polycomb recruitment and H2A ubiquitination. Science 318, 447-450.

Lessard, J., and Sauvageau, G. (2003). Bmi-1 determines the proliferative capacity of normal and leukaemic stem cells. Nature 423, 255-260.

Li, X. S., Trojer, P., Matsumura, T., Treisman, J. E., and Tanese, N. (2010). Mammalian SWI/SNF-a subunit BAF250/ARID1 is an E3 ubiquitin ligase that targets histone H2B. Mol. Cell. Biol. 30, 1673-1688.

Lin, W., Cao, J., Liu, J., Beshiri, M. L., Fujiwara, Y., Francis, J., Cherniack, A. D., Geisen, C., Blair, L. P., Zou, M. R., Shen, X., Kawamori, D., Liu, Z., Grisanzio, C., Watanabe, H., Minamishima, Y. A., Zhang, Q., Kulkarni, R. N., Signoretti, S., Rodig, S. J., Bronson, R. T., Orkin, S. H., Tuck, D. P., Benevolenskaya, E. V., Meyerson, M., Kaelin, W. G. Jr., and Yan, Q. (2011). Loss of the retinoblastoma binding protein 2 (RBP2) histone demethylase suppresses tumorigenesis in mice lacking Rb1 or Men1. Proc. Natl. Acad. Sci. U.S.A. 108, 13379-13386.

Liu, Z., Oughtred, R., and Wing, S. S. (2005). Characterization of E3Histone, a novel testis ubiquitin protein ligase which ubiquitinates histones. Mol. Cell. Biol. 25, 2819-2831.

Luger, K., Mader, A. W., Richmond, R. K., Sargent, D. F., and Richmond, T. J. (1997). Crystal structure of the nucleosome core particle at $2.8 \mathrm{~A}$ resolution. Nature 389, 251-260.

Lv, L., Xiao, X. Y., Gu, Z. H., Zeng, F. Q., Huang, L. Q., and Jiang, G. S. (2011). Silencing USP22 by asymmetric structure of interfering RNA inhibits proliferation and induces cell cycle arrest in bladder cancer cells. Mol. Cell. Biochem. 346, 11-21.

Ma, M. K., Heath, C., Hair, A., and West, A. G. (2011). Histone crosstalk directed by $\mathrm{H} 2 \mathrm{~B}$ ubiquitination is required for chromatin boundary integrity. PLoS Genet. 7, e1002175. doi:10.1371/journal.pgen.1002175

Mailand, N., Bekker-Jensen, S., Faustrup, H., Melander, F., Bartek, J., Lukas, C., and Lukas, J. (2007). RNF8 ubiquitylates histones at DNA double-strand breaks and promotes assembly of repair proteins. Cell 131, 887-900.

Mallery, D. L., Vandenberg, C. J., and Hiom, K. (2002). Activation of the E3 ligase function of the BRCA1/BARD1 complex by polyubiquitin chains. EMBO J. 21, 6755-6762.

Marteijn, J. A., Bekker-Jensen, S., Mailand, N., Lans, H., Schwertman, P., Gourdin, A. M., Dantuma, N. P. Lukas, J., and Vermeulen, W. (2009). Nucleotide excision repair-induced $\mathrm{H} 2 \mathrm{~A}$ ubiquitination is dependent on MDC1 and RNF8 and reveals a universal DNA damage response. J. Cell Biol. 186, 835-847.

Matsui, S. I., Seon, B. K., and Sandberg, A. A. (1979). Disappearance of a structural chromatin protein A24 in mitosis: implications for molecular basis of chromatin condensation. Proc. Natl. Acad. Sci. U.S.A. 76, 6386-6390.

Minsky, N., Shema, E., Field, Y., Schuster, M., Segal, E., and Oren, M. (2008). Monoubiquitinated H2B is associated with the transcribed region of highly expressed genes in human cells. Nat. Cell Biol. 10, 483-488.

Molofsky, A. V., Pardal, R., Iwashita, T., Park, I. K., Clarke, M. F., and Morrison, S. J. (2003). Bmi-1 dependence distinguishes neural stem cell selfrenewal from progenitor proliferation. Nature 425, 962-967.

Moyal, L., Lerenthal, Y., Gana-Weisz, M., Mass, G., So, S., Wang, S. Y., Eppink, B., Chung, Y. M., Shalev, G., Shema, E., Shkedy, D., Smorodinsky, N. I., van Vliet, N., Kuster, B., Mann, M., Ciechanover, A., DahmDaphi, J., Kanaar, R., Hu, M. C., Chen, D. J., Oren, M., and Shiloh, Y. (2011). Requirement of ATMdependent monoubiquitylation of histone $\mathrm{H} 2 \mathrm{~B}$ for timely repair of DNA double-strand breaks. Mol. Cell 41, 529-542.

Nakagawa, T., Kajitani, T., Togo, S., Masuko, N., Ohdan, H., Hishikawa, Y., Koji, T., Matsuyama, T., Ikura, T., Muramatsu, M., and Ito, T. (2008). Deubiquitylation of histone
$\mathrm{H} 2 \mathrm{~A}$ activates transcriptional initiation via trans-histone cross-talk with H3K4 di- and trimethylation. Genes Dev. 22, 37-49.

Nakamura, K., Kato, A., Kobayashi, J., Yanagihara, H., Sakamoto, S., Oliveira, D. V., Shimada, M., Tauchi, H., Suzuki, H., Tashiro, S., Zou, L. and Komatsu, K. (2011). Regulation of homologous recombination by RNF20-dependent H2B ubiquitination. Mol. Cell 41, 515-528.

Nicassio, F., Corrado, N., Vissers, J. H. Areces, L. B., Bergink, S., Marteijn, J. A., Geverts, B., Houtsmuller, A. B., Vermeulen, W., Di Fiore, P. P., and Citterio, E. (2007). Human USP3 is a chromatin modifier required for $S$ phase progression and genome stability. Curr. Biol. 17, 1972-1977.

Ogawa, H., Ishiguro, K., Gaubatz, S., Livingston, D. M., and Nakatani, Y. (2002). A complex with chromatin modifiers that occupies E2F- and Myc-responsive genes in G0 cells. Science 296, 1132-1136.

Pan, M. R., Peng, G., Hung, W. C., and Lin, S. Y. (2011). Monoubiquitination of $\mathrm{H} 2 \mathrm{AX}$ protein regulates DNA damage response signaling. J. Biol. Chem. 286, 28599-28607.

Park, I. K., Qian, D., Kiel, M., Becker, M. W., Pihalja, M., Weissman, I. L., Morrison, S. J., and Clarke, M. F. (2003). $\mathrm{Bmi}-1$ is required for maintenance of adult self-renewing haematopoietic stem cells. Nature 423, 302-305.

Pavri, R., Zhu, B., Li, G., Trojer, P., Mandal, S., Shilatifard, A., and Reinberg, D. (2006). Histone H2B monoubiquitination functions cooperatively with FACT to regulate elongation by RNA polymerase II. Cell 125, 703-717.

Pham, A. D., and Sauer, F. (2000). Ubiquitin-activating/conjugating activity of TAFII250, a mediator of activation of gene expression in Drosophila. Science 289, 2357-2360.

Prenzel, T., Begus-Nahrmann, Y., Kramer, F., Hennion, M., Hsu, C., Gorsler, T., Hintermair, C., Eick, D., Kremmer, E., Simons, M., Beissbarth, T., and Johnsen, S. A. (2011) Estrogen-dependent gene transcription in human breast cancer cells relies upon proteasome-dependent monoubiquitination of histone H2B. Cancer Res. 71, 5739-5753.

Querido, E., Blanchette, P., Yan, Q., Kamura, T., Morrison, M., Boivin, D., Kaelin, W. G., Conaway, R. C., Conaway, J. W., and Branton, P. E. (2001). Degradation of p53 by adenovirus E4orf6 and E1B55K proteins occurs via a novel mechanism involving a Cullin-containing 
complex. Genes Dev. 15, 3104-3117.

Robzyk, K., Recht, J., and Osley, M. A. (2000). Rad6-dependent ubiquitination of histone $\mathrm{H} 2 \mathrm{~B}$ in yeast. Science 287, 501-504.

Scheuermann, J. C., de Ayala Alonso, A. G., Oktaba, K., Ly-Hartig, N., McGinty, R. K., Fraterman, S., Wilm, M., Muir, T. W., and Muller, J. (2010). Histone H2A deubiquitinase activity of the polycomb repressive complex PR-DUB. Nature 465, 243-247.

Schulze, J. M., Hentrich, T., Nakanishi, S., Gupta, A., Emberly, E., Shilatifard, A., and Kobor, M. S. (2011). Splitting the task: Ubp8 and Ubp10 deubiquitinate different cellular pools of H2BK123. Genes Dev. 25, 2242-2247.

Shanbhag, N. M., Rafalska-Metcalf, I. U., Balane-Bolivar, C., Janicki, S. M., and Greenberg, R. A. (2010). ATM-dependent chromatin changes silence transcription in cis to DNA double-strand breaks. Cell 141, 970-981.

Shao, G., Lilli, D. R., Patterson-Fortin, J., Coleman, K. A., Morrissey, D. E., and Greenberg, R. A. (2009). The Rap80BRCC36 de-ubiquitinating enzyme complex antagonizes RNF8-Ubc13dependent ubiquitination events at DNA double strand breaks. Proc. Natl. Acad. Sci. U.S.A. 106, 3166-3171.

Shema, E., Kim, J., Roeder, R. G., and Oren, M. (2011). RNF20 inhibits TFIIS-facilitated transcriptional elongation to suppress prooncogenic gene expression. Mol. Cell $42,477-488$.

Shema, E., Tirosh, I., Aylon, Y., Huang, J., Ye, C., Moskovits, N., Raver-Shapira, N., Minsky, N., Pirngruber, J., Tarcic, G., Hublarova, P., Moyal, L., Gana-Weisz, M., Shiloh, Y., Yarden, Y., Johnsen, S. A., Vojtesek, B., Berger, S. L., and Oren, M. (2008). The histone H2B-specific ubiquitin ligase RNF20/hBRE1 acts as a putative tumor suppressor through selective regulation of gene expression. Genes Dev. 22, 2664-2676.

Sobhian, B., Shao, G., Lilli, D. R., Culhane, A. C., Moreau, L. A., Xia, B., Livingston, D. M., and Greenberg, R. A. (2007). RAP80 targets BRCA1 to specific ubiquitin structures at DNA damage sites. Science 316, 1198-1202.

Stewart, G. S., Panier, S., Townsend, K., Al-Hakim, A. K., Kolas, N. K., Miller, E. S., Nakada, S., Ylanko, J., Olivarius, S., Mendez, M., Oldreive, C., Wildenhain, J., Tagliaferro, A., Pelletier, L., Taubenheim, N., Durandy,
A., Byrd, P. J., Stankovic, T., Taylor, A. M., and Durocher, D. (2009). The RIDDLE syndrome protein mediates a ubiquitin-dependent signaling cascade at sites of DNA damage. Cell $136,420-434$.

Stewart, G. S., Wang, B., Bignell, C. R., Taylor, A. M., and Elledge, S. J. (2003). MDC1 is a mediator of the mammalian DNA damage checkpoint. Nature 421, 961-966.

Stock, J. K., Giadrossi, S., Casanova, M., Brookes, E., Vidal, M., Koseki, H., Brockdorff, N., Fisher, A. G., and Pombo, A. (2007). Ring1-mediated ubiquitination of $\mathrm{H} 2 \mathrm{~A}$ restrains poised RNA polymerase II at bivalent genes in mouse ES cells. Nat. Cell Biol. 9, 1428-1435.

Strahl, B. D., and Allis, C. D. (2000). The language of covalent histone modifications. Nature 403, 41-45.

Sun, Z. W., and Allis, C. D. (2002). Ubiquitination of histone $\mathrm{H} 2 \mathrm{~B}$ regulates $\mathrm{H} 3$ methylation and gene silencing in yeast. Nature 418, 104-108.

Testa, J. R., Cheung, M., Pei, J., Below, J. E., Tan, Y., Sementino, E., Cox, N. J., Dogan, A. U., Pass, H. I., Trusa, S., Hesdorffer, M., Nasu, M., Powers, A., Rivera, Z., Comertpay, S., Tanji, M., Gaudino, G., Yang, H., and Carbone, M. (2011). Germline BAP1 mutations predispose to malignant mesothelioma. Nat. Genet. 43, 1022-1025.

van der Knaap, J. A., Kumar, B. R., Moshkin, Y. M., Langenberg, K., Krijgsveld, J., Heck, A. J., Karch, F., and Verrijzer, C. P. (2005). GMP synthetase stimulates histone $\mathrm{H} 2 \mathrm{~B}$ deubiquitylation by the epigenetic silencer USP7. Mol. Cell 17, 695-707.

Wang, B., and Elledge, S. J. (2007). Ubc13/Rnf8 ubiquitin ligases control foci formation of the Rap80/Abraxas/Brca1/Brcc36 complex in response to DNA damage. Proc. Natl. Acad. Sci. U.S.A. 104, 20759-20763.

Wang, B., Matsuoka, S., Ballif, B. A., Zhang, D., Smogorzewska, A., Gygi, S. P., and Elledge, S. J. (2007). Abraxas and RAP 80 form a BRCA1 protein complex required for the DNA damage response. Science 316, 1194-1198.

Wang, H., Wang, L., ErdjumentBromage, H., Vidal, M., Tempst, P., Jones, R. S., and Zhang, Y. (2004). Role of histone $\mathrm{H} 2 \mathrm{~A}$ ubiquitination in polycomb silencing. Nature 431, 873-878.

Wang, H., Zhai, L., Xu, J., Joo, H. Y., Jackson, S., Erdjument-Bromage, H.,
Tempst, P., Xiong, Y., and Zhang, Y. (2006). Histone $\mathrm{H} 3$ and $\mathrm{H} 4$ ubiquitylation by the CUL4-DDB-ROC1 ubiquitin ligase facilitates cellular response to DNA damage. Mol. Cell $22,383-394$.

West, M. H., and Bonner, W. M. (1980). Histone 2B can be modified by the attachment of ubiquitin. Nucleic Acids Res. 8, 4671-4680.

Wiesner, T., Obenauf, A. C., Murali, R., Fried, I., Griewank, K. G., Ulz, P., Windpassinger, C., Wackernagel, W., Loy, S., Wolf, I., Viale, A., Lash, A. E., Pirun, M., Socci, N. D., Rutten, A., Palmedo, G., Abramson, D., Offit, K., Ott, A., Becker, J. C., Cerroni, L., Kutzner, H., Bastian, B. C., and Speicher, M. R. (2011). Germline mutations in BAP1 predispose to melanocytic tumors. Nat. Genet. 43 , 1018-1021.

Wissmann, M., Yin, N., Muller, J. M., Greschik, H., Fodor, B. D., Jenuwein, T., Vogler, C., Schneider, R., Gunther, T., Buettner, R., Metzger, E., and Schule, R. (2007). Cooperative demethylation by JMJD2C and LSD1 promotes androgen receptordependent gene expression. Nat. Cell Biol. 9, 347-353.

Wood, A., Krogan, N. J., Dover, J., Schneider, J., Heidt, J., Boateng, M. A., Dean, K., Golshani, A., Zhang, Y., Greenblatt, J. F., Johnston, M., and Shilatifard, A. (2003). Bre1, an E3 ubiquitin ligase required for recruitment and substrate selection of Rad6 at a promoter. Mol. Cell 11, 267-274.

Wu, C. Y., Kang, H. Y., Yang, W. L., Wu, J., Jeong, Y. S., Wang, J., Chan, C. H., Lee, S. W., Zhang, X., Lamothe, B., Campos, A. D., Darnay, B. G., and Lin, H. K. (2011) Critical role of monoubiquitination of histone $\mathrm{H} 2 \mathrm{AX}$ protein in histone $\mathrm{H} 2 \mathrm{AX}$ phosphorylation and DNA damage response. J. Biol. Chem. 286 , 30806-30815.

Wu, J., Huen, M. S., Lu, L. Y., Ye, L., Dou, Y., Ljungman, M., Chen, J., and Yu, X. (2009). Histone ubiquitination associates with BRCA1-dependent DNA damage response. Mol. Cell. Biol. 29, 849-860.

Wyce, A., Xiao, T., Whelan, K. A., Kosman, C., Walter, W., Eick, D., Hughes, T. R., Krogan, N. J., Strahl, B. D., and Berger, S. L. (2007). H2B ubiquitylation acts as a barrier to Ctk1 nucleosomal recruitment prior to removal by Ubp8 within a SAGA-related complex. Mol. Cell 27, 275-288.

Xia, Y., Pao, G. M., Chen, H. W., Verma, I. M., and Hunter, T. (2003).
Enhancement of BRCA1 E3 ubiquitin ligase activity through direct interaction with the BARD1 protein. J. Biol. Chem. 278, 5255-5263.

Xiao, T. J., Kao, C. F., Krogan, N. J., Sun, Z. W., Greenblatt, J. F., Osley, M. A., and Strahl, B. D. (2005). Histone H2B ubiquitylation is associated with elongating RNA polymerase II. Mol. Cell. Biol. 25, 637-651.

Xu, X. Z., and Stern, D. F. (2003). NFBD1/KIAA0170 is a chromatinassociated protein involved in DNA damage signaling pathways. J. Biol. Chem. 278 8795-8803.

Yan, Q., Kamura, T., Cai, Y., Jin, J., Ivan, M., Mushegian, A., Conaway, R. C., and Conaway, J. W. (2004) Identification of Elongin $\mathrm{C}$ and Skp1 sequences that determine Cullin selection. J. Biol. Chem. 279, 43019-43026.

Yokoyama, A., Wang, Z., Wysocka, J., Sanyal, M., Aufiero, D. J., Kitabayashi, I., Herr, W., and Cleary, M. L. (2004). Leukemia protooncoprotein MLL forms a SET1like histone methyltransferase complex with menin to regulate Hox gene expression. Mol. Cell. Biol. 24, 5639-5649.

Zhang, X. Y., Varthi, M., Sykes, S. M., Phillips, C., Warzecha, C., Zhu, W., Wyce, A., Thorne, A. W., Berger, S. L., and McMahon, S. B. (2008). The putative cancer stem cell marker USP22 is a subunit of the human SAGA complex required for activated transcription and cellcycle progression. Mol. Cell 29, 102-111.

Zhang, Y. X., Yao, L., Zhang, X. Y., Ji, H. F., Wang, L. H., Sun, S. S., and Pang, D. (2011). Elevated expression of USP22 in correlation with poor prognosis in patients with invasive breast cancer. J. Cancer Res. Clin. Oncol. 137, 1245-1253.

Zhao, Y., Lang, G., Ito, S., Bonnet, J., Metzger, E., Sawatsubashi, S., Suzuki, E., Le Guezennec, X., Stunnenberg, H. G., Krasnov, A., Georgieva, S. G., Schule, R., Takeyama, K., Kato, S., Tora, L., and Devys, D. (2008). A TFTC/STAGA module mediates histone $\mathrm{H} 2 \mathrm{~A}$ and $\mathrm{H} 2 \mathrm{~B}$ deubiquitination, coactivates nuclear receptors, and counteracts heterochromatin silencing. Mol. Cell 29 , 92-101.

Zhou, W., Zhu, P., Wang, J., Pascual, G., Ohgi, K. A., Lozach, J., Glass, C. K., and Rosenfeld, M. G. (2008). Histone $\mathrm{H} 2 \mathrm{~A}$ monoubiquitination 
represses transcription by inhibiting RNA polymerase II transcriptional elongation. Mol. Cell 29, 69-80.

Zhu, B., Zheng, Y., Pham, A. D., Mandal, S. S., Erdjument-Bromage, H., Tempst, P., and Reinberg, D. (2005). Monoubiquitination of human histone $\mathrm{H} 2 \mathrm{~B}$ : the factors involved and their roles in HOX gene regulation. Mol. Cell 20, 601-611.

Zhu, P., Zhou, W., Wang, J., Puc, J., Ohgi, K. A., Erdjument-Bromage,
H., Tempst, P., Glass, C. K., and Rosenfeld, M. G. (2007). A histone H2A deubiquitinase complex coordinating histone acetylation and $\mathrm{H} 1$ dissociation in transcriptional regulation. Mol. Cell 27 , 609-621.

Zhu, Q., Pao, G. M., Huynh, A. M., Suh, H., Tonnu, N., Nederlof, P. M., Gage, F. H., and Verma, I. M. (2011). BRCAl tumour suppression occurs via heterochromatinmediated silencing. Nature 477, 179-184.
Conflict of Interest Statement: The authors declare that the research was conducted in the absence of any commercial or financial relationships that could be construed as a potential conflict of interest.

Received: 17 January 2012; paper pending published: 30 January 2012; accepted: 21 February 2012; published online: 12 March 2012.

Citation: Cao J and Yan Q (2012) Histone ubiquitination and deubiquitination in transcription, DNA damage response, and cancer. Front. Oncol. 2:26. doi: 10.3389/fonc.2012.00026

This article was submitted to Frontiers in Molecular and Cellular Oncology, a specialty of Frontiers in Oncology.

Copyright $\odot 2012$ Cao and Yan. This is an open-access article distributed under the terms of the Creative Commons Attribution Non Commercial License, which permits non-commercial use, distribution, and reproduction in other forums, provided the original authors and source are credited. 